
\title{
28 Research Suare \\ Wintertime Cold and Warm Spells in The Eastern Part of The Baltic Sea Region
}

Indrè Gečaitė ( $\nabla$ indre.gecaite@chgf.vu.It )

Vilnius University: Vilniaus Universitetas https://orcid.org/0000-0001-6870-4862

Egidijus Rimkus

Vilnius University: Vilniaus Universitetas

\section{Research Article}

Keywords: temperature extremes, cold spells, warm spells, the Baltic sea region, regime shift

Posted Date: March 7th, 2022

DOI: https://doi.org/10.21203/rs.3.rs-1401649/v1

License: (9) This work is licensed under a Creative Commons Attribution 4.0 International License. Read Full License 


\section{Abstract}

One of the most important uncertainties in a changing climate conditions are changes in climate extremes. While precipitation extremes are particularly important at low latitudes, thermal extremes are of major interest at mid-latitudes. This study analyses the cold (CS) and warm (WS) spells winter climatology in the eastern part of the Baltic Sea region from 1951 till 2020. Data from the E-OBS database were used in the research. A CS/WS in this study is an event when extreme low/high (below 10th/above 90th percentile) air temperature persists for at least 5 days. The period 1971-2000 was used as the climate norm. The results show that both absolute winter air temperature minimum and maximum increased over the investigation period. The absolute maximum of winter air temperature strongly increased after 1988, when a statistically significant regime shift was determined. The results show that the number of WSs have increased and changes are statistically significant in most cases. Meanwhile, the recurrence and duration of CSs have changed insignificantly, although the number of years with more than one CSs is decreasing. The total number of CS/WS cases per season slightly increased. Total number of WSs days increased a lot at the last decade of the investigation period, while the number of CSs days changed insignificantly in recent several decades.

\section{Introduction}

The last three decades in Europe have been characterized by rapid air temperature rise and increased frequency of extreme weather events such as droughts, summer heat waves, windstorms, heavy precipitation events, and floods. This great scientific and public interest to extreme events remains especially relevant under the changing climate conditions. Comprehensive research of extreme weather events is particularly important for the middle latitudes, as the inter-annual variability of the climate is evident. Some studies (Rutgersson et al. 2015) have found that the climate warming in Northern Europe is faster than the global mean.

There has been a great deal of interest in cold waves in 2010, when large-scale cold waves were observed in many parts of the Northern Hemisphere $(\mathrm{NH})$, especially in Europe (Christiansen et at. 2018; Guirguis et al. 2011). It is well known that a sudden drop of air temperature can significantly affect human health. Some scientific studies (Gasparrini et al. 2015) have shown that people die from the severe cold several times more often than from heat. For this reason, each region has its official thresholds of negative temperature, beyond which it is recommended to stay at home, especially for vulnerable groups such as elders, children, and people with certain medical conditions. Severe winters have always brought a lot of damage in various areas of human activity. CSs have a negative effect on the transport and communication sector and can also cause serious damage to buildings. During severe cold periods, gas consumption and heating costs increase significantly. Finally, interchangeable occurrence of extremely warm and cold periods may have a negative effect on agriculture, food, and livestock production (McMichael et al. 2007). Considering the negative impact mentioned above, the accurate prediction of severe CSs and WSs is an important and challenging task in sub-seasonal and seasonal weather forecasting. 
Despite rapid global warming over the last decades, when the average air temperature during winter was recorded above normal, there were also periods when the air temperature dropped to extremely low values. The recent winters of 2009-2013, 2017-2018 in Europe, and 2013-2015, 2017-2019 in North America had several severe CSs events and aroused scientific and media attention on those costly episodes of extreme temperatures.

Some studies (Kharin et al. 2007; Claud et al. 2007; Kodra et al. 2011; Mori et al. 2014; Vihma 2014) have shown that the probability of significant cold anomalies in the future will persist. Moreover, CSs may be even stronger. Results from the simulation reveal that the recent Arctic sea ice reduction contributes to reoccurrence of cold winters in some mid-latitude continental regions (Cohen et al. 2018; Nakamura et al. 2015). This was explained as a result of the Arctic amplification, which means the stronger warming of the poles to compare with lower latitudes (Vallis et al. 2015). This seesaw Northern hemisphere winter temperature phenomenon also is called "warm Arctic - cold continents pattern" (Overland et al. 2011).

Together with the mentioned amplification, a decrease in the meridional temperature gradient and weakening of the polar jet stream was observed (Francis et al. 2009; Outten and Esau 2012). The eddy heat flux has also robustly weakened over the last four decades (Vallis et al. 2015; Chemke and Polvani 2020). This creates favourable conditions for the formation of cold anomalies, which are often related to a perturbed jet stream (Francis and Vavrus 2012). High meandering of the polar front jet stream causes a deep southward intrusion of cold Arctic air over the continent (Tang et al. 2013; Vihma 2017; Vavrus 2018; Cohen et al. 2020). Due to the Arctic amplification the WSs in the North Pole also become much stronger and more common, in some cases anomalies are as high as $30^{\circ} \mathrm{C}$ (Graham et al. 2017). The relationship between temperature anomalies in Arctic and mid-latitude continents, and weaker zonal winds, was once again confirmed by Vihma et al. (2020). Thus, the increased intensity of winter CSs in one region can also be linked to increased intensity of WSs in another (Cohen et al. 2018). Recent extended CSs occurred during a period, which is called a "hiatus" period, when the trend of annual global mean surface temperature remained almost steady (Johnson et al. 2018).

Severe CSs in Europe are often associated with blocking processes over the North Atlantic. This situation is characterized by anticyclonic circulation, which creates favourable conditions for the intrusion of cold air from the north. It is important to note, that the specific location of the atmospheric blocking events over the North Atlantic creates different patterns of temperature extremes in Europe. Blocking processes in the western part of the Atlantic are not so important for the formation of cold anomalies in Europe (Sillmann and Croci-Maspoli 2009). It has also been established that the close relationship between anomalous winter temperatures and blocking processes will remain in the future climate (Sillmann et al. 2011).

Winters WSs in Europe received considerably less attention comparing to the number of studies related to cold waves. However, it is very likely that winter WSs are becoming more frequent, longer lasting, and more intense with a rapidly warming climate in $\mathrm{NH}$ mid-latitudes. Statistically significant increase in extremely warm days in winter in Northern Europe during 1979-2016 was found in a study by Sui et al. 
(2020). The increase in wintertime air temperature in Central Europe has been detected by Tomczyk et al. (2019), however most of these changes were statistically insignificant. In this study, large-scale WSs have been associated with the advection of warm air masses and anomalies in geopotential height in the entire troposphere, with the largest anomalies at $250 \mathrm{hPa}$ several days before the extreme event. In the study by Matthes et al. (2015), it was determined that in winter WSs strengthened for most of the European and western Russian stations, with trends of up to 2.5 days per decade and statistically significant trends over Scandinavia. However, in the same research, statistically significant decrease in WSs of up to 2.5 days per decade were found in some stations in Siberia. The decreasing number of winter warm days was also found for Greece (Efthymiadis et al. 2011).

This can play a considerable role in biochemistry, changes in ecosystems, primary production, and dynamics of an agricultural pest species (Ma et al. 2018; Chapman et al. 2020). Extended warm and cold periods, as well as changes in the freeze-thaw cycle, have a negative impact on structure and functioning of ecosystems, seasonal cycles development, and survival rates of different organisms (Jiguet et al. 2011; $\mathrm{Ma}$ et al. 2015). In addition, a return of cold winter conditions can lead to plants tissue damage and its further development during spring (Chapman et al. 2020). Thus, detailed studies of WSs are necessary to understand the mechanism of their formation and the further procedures of improving their predictions. Usually, increased reoccurrences and intensity of WSs in the winter is attributed to a longterm global warming trend and CSs of the same winter are often assigned to the state of regional climate patterns (Guirguis et al. 2011). However, it is also possible that they are both a consequence of the same trigger during the winter period.

Currently, the discussion whether the number of extreme temperature events is increasing or decreasing is becoming especially relevant. The first-order hypothesis is that, in a warming climate, WSs are becoming more frequent and long lasting, and CSs are much rarer and less cold. There are many studies related to extreme temperature drivers, but the understanding of long-term tendencies in extreme temperature events is pivotal for setting further guidelines for climate change adaptation. It is also very important to distinguish between different approaches to extreme temperature events and to pay special attention to the importance of selection of the climate norm. These differences may also lead to different interpretations of the results.

In this article, we studied wintertime temperature extremes in the eastern part of the Baltic Sea region over the last 70 years (1951-2020). To evaluate and describe long term cold and warm anomalies, we use 3 different parameters: absolute maximum and minimum seasonal air temperature, 90/10 percentiles, and 10-year return level. We believe that such comprehensive study will provide more clarity on the change of temperature anomalies in a studied region.

\section{Data And Methods}

\subsection{Study Area}


Our studied area is the eastern part of the Baltic Sea region, defined here as latitudes between $52^{\circ}$ and $62^{\circ} \mathrm{N}$ and longitudes between $20^{\circ}$ and $32^{\circ} \mathrm{E}$. Data matrices contain 97 grid points (only land points as shown in Fig. 1). The choice of this area was partly determined by the coverage of the geographical area of other studies on this topic, where most of the territory of the Eastern Baltic region is usually excluded (Vihma 2020; Sulikowska and Wypych 2021).

Our studied territory falls into the Dfb climate subtype according Köppen's classification (warm-summer humid continental climate). The precipitation is evenly distributed throughout the year and ranges from $25 \mathrm{~mm}$ to $52 \mathrm{~mm}$ in January and from $52 \mathrm{~mm}$ to $84 \mathrm{~mm}$ in July. The temperature during the warmest month (July) varies from $16.2^{\circ} \mathrm{C}$ in the northwest of the analysed region to $19.2^{\circ} \mathrm{C}$ in the south-eastern part (the mean air temperatures calculated for the whole investigation period 1951-2020) (Fig. 1). During the winter, regional differences of mean air temperature increase significantly comparing to summer months. January is the coldest month of the year and temperature ranges from $-2.3^{\circ} \mathrm{C}$ in the southwest to $-8.7^{\circ} \mathrm{C}$ in the northeast (Fig. 1).

\subsection{Definition of Cold and Warm Spells}

There is a lack of rigorous definitions for CSs and WSs. However, most often CS/WS are described as a prolonged period with extremely low/high temperature relative to local conditions (climatic norm). CS/WS are typically defined as an extreme temperature event exceeding specific temperature threshold over some short time interval, usually expressed in number of days. Different variations of CS/WS evaluation methods were well described in the study by Domonkos and Piotrowicz (1998). The choice of method also highly depends on the type of the research purpose. The IPCC has proposed that an event is defined as extreme (or rare) when the recurrence of a particular quantity is less than the 10th or greater than the 90th percentile (IPCC, 2001). This definition is often applied in extreme temperature studies (Nikolova and Penev 2007; Tomassini et al. 2012; Matthes et al. 2015; Spinoni et al. 2015; Johnson et al. 2018; Lavaysse et al. 2019; Smid et al. 2019) and will be used in this study as well. To determine extremely cold/warm periods, daily minimum ( $T n$ ) and maximum ( $T x$ ) temperature data are used. However, we found disagreements in the definition of CS/WS length. In different studies this number varies significantly from 3 to 15 consecutive days (Tomassini et al. 2012; Lhotka and Kyselý 2015; Matthes et al. 2015; Spinoni et al. 2015; Tomczyk et al. 2019). In our study, we chose a 5 day period to define CSs and WSs.

\subsection{Reference Period}

The definition of temperature extremes during the long-time interval is very problematic, because of the significant differences in climatic norms. It is especially important to choose an appropriate period that we will consider as a climatic norm. This also depends on the purpose of a study and on the meteorological parameter itself. In meteorology, it is agreed to take a 30 year time interval as the climatic norm. The choice of the wrong period can significantly affect the results of the analysis. That is why the understanding of an extreme event is closely related with our perception of what a normal state is. The 
effect of a gradual temperature increase during the last decades makes this task even more difficult because it is obvious that current extremes may become the near future norms or vice versa.

For this reason, the important part of this study was to determine which climate norm should be used. In recent years, the climatic norm of 1981-2010 was most used (Vihma et al. 2020; Sui et al. 2020). First, we decided to examine extreme temperature fluctuations over the last 70 years. For this purpose, regionally averaged seasonal minimum $\mathrm{Tn}(\mathrm{TNn})$ and maximum $\mathrm{Tx}(\mathrm{TXx})$ temperatures were applied (calculated for each grid point separately and then averaged over the entire region). It turned out that the average wintertime regional $\mathrm{TNn}$ varied over a wide range from $-8.1^{\circ} \mathrm{C}(2020)$ to $-34.7^{\circ} \mathrm{C}(1956)$. Meanwhile, TXx fluctuations were much smaller from $1.3^{\circ} \mathrm{C}(1963)$ to $11.8^{\circ} \mathrm{C}(1990)$. The significance $(\mathrm{p}$ $<0.05)$, according to the Mann-Kendal test positive trend, was determined for TXX $\left(0.56^{\circ} \mathrm{C}\right.$ per decade), while slightly smaller positive trend for $\operatorname{TNn}\left(0.43^{\circ} \mathrm{C}\right.$ per decade) was found to be insignificant due to high variation of this parameter (Fig. 2). The standard deviation for $\mathrm{TNn}$ is $4.7^{\circ} \mathrm{C}$ and $2.3^{\circ} \mathrm{C}$ for $\mathrm{TXX}$.

Initial data analysis allowed us to detect sudden change in an average extreme temperature over a short period of time (Fig. 2). We used "Sequential Regime Shift Detection Software" (version: 6.2.1) proposed by Rodionov (2004) to detect regime shifts in the data series. We found statistically significant $(p<0.05)$ regime shift in 1988 in maximum (TXX) temperatures series, while changes in TNn were insignificant. The whole analysed period can be divided into two periods: 1951-1987 and 1988-2020. The difference in mean values between these two periods is $1.6^{\circ} \mathrm{C}$ for the $\mathrm{TNn}$ and $2.7^{\circ} \mathrm{C}$ for the $\mathrm{TXx}$. However, during these two periods, the regionally averaged extreme temperature parameters showed little change (except TNn in 1988-2020) or even an insignificant negative tendency. This is particularly evident in the fluctuations of TXX.

After splitting into two periods, both TNn and TXx tendencies during 1951-1987 became negative and equal to $-0.46^{\circ} \mathrm{C}$ and $-0.01^{\circ} \mathrm{C}$ per decade, respectively. During the second period (1988-2020), the tendency for $\mathrm{TNn}$ equals to $0.4^{\circ} \mathrm{C}$ and for $\mathrm{TXx}$ is $-0.3^{\circ} \mathrm{C}$ per decade. However, these tendencies are not statistically significant. It is also very important to note that 2020 was the warmest year in the last 70 years and had a major impact on the TNn trend. If we exclude it from the calculation, the trend for 19882019 would be negative.

We verified this statement and found that the shift in air temperature regime around 1988 corresponds particularly well to changes in large-scale atmospheric circulation (LSAC), such as Arctic oscillation (AO). We also found statistically significant $(p<0.05)$ regime shift in 1989 in wintertime AO data series (Fig. 2c). The correlation coefficient between winter (DJF) AO and regionally averaged TNn is 0.57 and 0.72 for TXx. Both correlations are statistically significant. A slight increase in the mean DJF AO index was observed between 1951 and 1988 and a significant decrease between 1989 and 2020. This shift in LSAC has often been mentioned in previous studies. Figura et al. (2011) found that sudden changes in groundwater temperature in Switzerland were associated with a shift in LSAC in the late 1980s. Changes in snow cover melting dates were also associated with a significant shift in AO regime in 1988/1989 (Foster et al. 2013). In addition, changes in the regime were observed in all European seas in the late 
1980s. These changes have been associated with changes in pressure distribution across the Atlantic, such as the North Atlantic oscillation (NAO) index, and with changes in sea temperature (Beaugrand et al. 2015; Conversi et al. 2010).

Based on information given above a climate norm covering both periods, $1970-2000$ was chosen for further analysis of the CSs and WSs. We used the climate norm of 1970-2000 as a "bridge" between relatively cold and warm periods. The 1971-2000 climate norm was also used to analyse changes in thermal seasons in Northern Europe (Ruosteenoja et al. 2020).

\subsection{Initial Data and Analysis Methods}

We used E-OBS daily Tn and Tx gridded data from the latest E-OBS (version 23.1e) dataset on a $0.25^{\circ}-$ $0.25^{\circ}$ longitude-latitude grid (Cornes et al. 2018). We analysed only winter months from DJF season. Winter of 1951 in our study is defined as winter December 1950-February 1951. Different parameters which describe severity, duration, and frequency of CSs/WSs were evaluated based on three different methods:

1) We used absolute seasonal daily minimum ( $T n$ ) and maximum ( $T x)$ values to evaluate the severity of inter-annular cold/warm anomalies. This method was also used in different studies (Karl et al. 1999; Alexander et al. 2006; Van Oldenborgh et al. 2015, 2019). For Tx, we calculated maximum values using only the Tx data of January and February (JF), as they are the coldest months of the year. Finally, the linear trends were computed using Sen's slope estimator. We used a nonparametric Mann-Kendal test to evaluate changes during the past 70 years. We applied $95 \%$ statistical significance level.

2) We detected all WSs and CSs in every grid point throughout the period 1951-2020. CSs/WSs were determined whenever $\mathrm{Tn} / \mathrm{Tx}$ is above the 90th percentile (below the 10th percentile) for at least 5 consecutive days and with a break of no more than two days between two separate events. We computed the daily percentile values versus the 1971-2000 baseline on a 5 day centred window (Sillmann et al. 2013). The climatology of CSs/WSs frequency, intensity, and duration was evaluated.

3) We also used generalized extreme value (GEV) distribution to estimate 10 year return values $\left(R L_{10}\right)$. Return level $(\mathrm{RL})$ is a very informative indicator allowing us to evaluate extreme temperature characteristics and changes over the long time frame. Calculations were made for five different time intervals (1951-1980, 1961-1990, 1971-2000, 1981-2010, and 1991-2020). This was done for each grid point by fitting Tn and Tx for each cold season (for Tx only JF) to a GEV distruibution using a loglikelihood method as described in Coles (2001). The GEV distribution was successfully applied in a variety of different studies of extreme temperatures (Rusticucci and Tencer 2008; Sillman et al. 2011). The maximum likelihood method and L-moments are most used in such studies (Hosking 1990), however, Anagnostopoulou et al. (2017) showed that L-moments are the less appropriate method for temperature parameters. $\mathrm{RL}_{10}$ calculation was done using the climextRemes software package (Paciorek et al. 2018) within R library built upon the extRemes library (Gilleland and Katz 2016), which is available at https://cran.r-project.org/web/packages/climextRemes/index.html. We also applied the KolmogorovSmirnov test to measure the agreement between the empirical and GEV distributions. 


\section{Results}

\subsection{Changes in Absolute Seasonal Tn and Tx Temperature}

Analysis of the absolute seasonal Tn an Tx temperatures throughout the period 1951-2020 showed notable changes in air temperature extremes. The absolute seasonal daily minimum temperature $(\mathrm{Tn})$ increased in the entire territory, while in the central part, changes were statistically significant (Fig. 3a). In these grid points the trend values reached $0.70-0.96^{\circ} \mathrm{C}$ per decade. The median value in the investigated area is $0.44^{\circ} \mathrm{C}$ per decade.

However, if the analysed period would be divided into two parts (as described in the previous section), negative changes prevailed from 1951 till 1987. In some grid cells in the northern part of territory, the changes are statistically significant and trend values were even below $-2^{\circ} \mathrm{C} /$ decade (Fig. $3 \mathrm{~b}$ ). Median trend value is $-0.37^{\circ} \mathrm{C}$ per decade. During the second period (1988-2020), insignificant positive tendencies dominate over the studied territory (Fig. 3c). The median value of trends is equal to $0.58^{\circ} \mathrm{C}$ per decade. However, several grid points with statistically insignificant negative tendencies were identified in the south-western and north-western parts of the analysed area. Nevertheless, the last few warm winters (especially in 2020) have had a decisive influence on the trend sign and value. During the period from 1988 to 2017 , we had predominantly negative trends with a median value $-0.29^{\circ} \mathrm{C}$ per decade.

Slightly different changes were observed in absolute seasonal daily maximum temperatures (Tx): positive by taking the whole period and prevailing negative by dividing it into two parts (Fig. 4). The changes during the entire period are slightly larger than in case of $\mathrm{Tn}$. The median value equals $0.57^{\circ} \mathrm{C} / \mathrm{decade}$ during the entire period and changes are statistically significant in all grid cells. Most prominent TX changes occurred in the southwest. In some grid points, Tx trend values reached $0.70-0.73^{\circ} \mathrm{C}$ per decade. The smallest changes were found in the northeast (Fig. 4a).

Meanwhile, trend values in 1951-1987 have clear territorial differences. Insignificant negative changes were observed in west while positive in the east (in one grid cell changes are significant) (Fig. 4b). However, during the period of 1988-2017, the negative insignificant changes were detected almost in the entire territory (Fig. 4C). The median trend value of this period equals to $-0.26^{\circ} \mathrm{C}$ per decade, while the largest changes were in the southwest of the territory. This suggests that the regime shift in $\mathrm{Tx}$ in the late 80 s was unprecedentedly large.

\subsection{Climatology of CSs and WSs Frequency}

A CS/WS in this study is an event when extreme low/high (below 10th /above 90th percentile) temperatures persist for at least 5 days. If the time interval between two CSs is equal to one or two days, it is the same event. Such events were counted for every cold season of each year in 1951-2020.

On average, CSs were recorded 5 years per decade, while the average number of CSs is 7-10 per decade. Typically, 1 to 3 CSs can be observed during a single DJF season. However, some years have been 
characterized by a particularly frequent recurrence of CSs. In those years, as many as 4-6 CSs per one season were recorded, and most of these winters were extremely cold (Fig. 5a).

However, it can be noticed, that the last winter season with 4 or more CSs was observed 35 years ago. There were also some years without CSs, which in most cases are very warm winters. Those winters were marked by red asterisks in Fig. 5a. The number of such years has increased in recent decades, and the wintertime warm temperature records in 2020 have no precedent over the last 70 years.

Figure 6 shows the total number of CSs during different decades. The highest number of CSs was observed in 1961-1970 when the total number of such events ranges from 10 to 22 (median is 15) with the highest number in the central part of investigation area. The decade of 1951-1960 can also be described as a decade with a high number of CSs, the total number ranges from 3 to 15 (median is 10). However, no major changes can be observed during the last 5 decades. Usually 5-8 CSs per decade are observed. There has also been little change in the number of years with at least one CS per decade, which is about 5 years. Based on these results, cold spells in the region may be expected every two years.

During the analysed period, the average number of WSs is 6-9 per decade. But this number has changed dramatically in recent decades compared with previous ones, increasing from 2-9 (1951-1990) to 7-15 (1991-2020) (Fig. 7). A significant increase in the number of WSs has been observed since 1989. At the same time, the number of years with at least one WS has also increased from 3-5 (1951-1990) to 5-8 (1991-2020) per decade. Over the last decade in the northern part of the studied region, WSs have been recorded almost annually. The largest changes were observed in the south-southeast of the studied area, while the smallest in the north-western part.

The highest frequency of WSs was recorded in the last two decades: the median was 10 WSs per decade in 2001-2010 and 15 WSs per decade in 2011-2020. In some years, there were as many as 4-6 warm spells in one season and all of them were recorded after 1988 (Fig. 5b). The lowest number of WSs was observed in 1961-1970 (median value is 2 WSs per decade). Some years were without a WSs in the entire region (Fig. 5b).

The general tendencies of CSs/WSs in the region are presented in Fig. 8. WSs have been observed much more frequently in recent years, but recurrences of CSs did not decrease significantly. In some years during the 21st century, the recurrence of CSs in the analysed region exceeded the number of WSs (Fig. 8). However, the trend in the difference between WSs and CSs is positive and statistically significant. It should be mentioned that the total amount of CSs and WSs in the region is increasing (although changes are statistically insignificant). This tendency is particularly unfavourable for the ecosystems, agriculture, and horticulture. For example, in 2012, in the south-eastern part of the region, there were 3 WSs in December and 2 CSs in February; in 2016 in the north of the region there were also 3 WSs (in December and February) and 2 CSs in January during the same winter season.

\subsection{Total Number of Days with CCs/WSs}


Duration of CSs/WSs is another indicator which allows us to evaluate the extremeness of these events as well as winter conditions. On average, one CSs last for 9 days in the analysed region. It cannot be said that CSs last longer in the north or south, this number differed a lot in different years.

Analysing the total sum of CSs days in different decades, it was found that the largest duration of the CSs was observed in 1961-1970 (Fig. 9). The total number of CSs days was estimated to be up to 220 days (median value is 168 days) per decade. This was due to several extremely cold winters with longlasting CSs: 1963, 1964, 1966, 1967, 1968, 1970. Long lasting CSs were also observed in 1951-1960 (median value is 98 days) and 1981-1990 (median value is 94 days). The CSs of 1985 and 1987 were extremely severe in terms of both low temperature and duration (at some points, individual CS lasted for 20 days or more).

The smallest number of CSs days was determined in 1991-2000 (median value is only 41 days, which is four times less than in 1961-1970). During this decade, the longest CSs were observed in the winters of 1996 and 1997, but their duration was only slightly above the average. Over the last two decades, the total duration of the CSs ranged from 38 to 94 days (longer in the north). There were also several CSs which lasted 15 to 19 days $(2002,2003,2011$ and 2012).

It was determined that WSs on average also last 9 days. The largest number of WSs days were observed in 2011-2020, when the total duration ranged from 118 days per decade in the southeast, to 241 days per decade in the north (Fig. 10). The unusually warm 2020 made a significant contribution to these numbers. It should be mentioned that decade of 2001-2010 was also marked by prolonged WSs. The average WSs duration of the winters 2002 and 2007 were particularly long, on average the number of WSs days was 20 and 42 days, respectively. However, the largest values were recorded in 2020, when an average sum of winter WSs over the region was 54 days. The shortest duration of WSs were observed in 1961-1970 (10-46 days per decade) (Fig. 10). These results confirm that, along with climate change, WSs are not only becoming more frequent but also longer lasting.

\subsection{Climatology of Tn and Tx Return Level}

We calculated return level (RL) for 5 different 30 year intervals: 1951-1980, 1961-1990, 1971-2000, 1981-2010, and 1991-2020. By comparing RLs of different time periods, it is possible to evaluate how $\mathrm{RL}$ values, which may occur once every 10 years, are changing in the context of climate change. The 10 year $\mathrm{RL}\left(\mathrm{RL}_{10}\right)$ statistics for $\mathrm{TNn}$ and $\mathrm{TXx}$ are presented in the Table 1.

Comparing different time intervals over the last 70 years, we found that the regional minimum value of $\mathrm{TNn} \mathrm{RL}{ }_{10}$ has changed slightly $\left(1.5^{\circ} \mathrm{C}\right.$ ), while the maximum value has increased more significantly (by $3.7^{\circ} \mathrm{C}$ ). Whereas the standard spatial deviation of the extreme values within the region are decreasing (Table 1).

The opposite tendencies for $\mathrm{Tx}_{\mathrm{RL}} \mathrm{L}_{10}$ values were noticed. The largest difference between minimum $\mathrm{Tx}$ $\mathrm{RL}_{10}$ value was $2.4^{\circ} \mathrm{C}$. However, comparing the values of the last few decades, $\mathrm{Tx} \mathrm{RL}_{10}$ have changed 
insignificantly. The same applies to the maximum values. The largest difference between maximum Tx $\mathrm{RL}_{10}$ value was $2.9^{\circ} \mathrm{C}$, but again, negligible changes were observed during the last three periods (Table 1).

Table 1

TNn and TXX 10 year return level of absolute minimum (MIN) and maximum (MAX) air temperature averaged over entire region and standard deviation (STD)

\begin{tabular}{|lllllll|}
\hline Years & \multicolumn{3}{c}{$\mathrm{TNn} \mathrm{RL}_{10},{ }^{\circ} \mathrm{C}$} & \multicolumn{4}{c|}{$\mathrm{TXX} \mathrm{RL}_{10}{ }^{\circ} \mathrm{C}$} \\
\cline { 2 - 7 } & MIN & MAX & STD & MIN & MAX & STD \\
\hline $1951-1980$ & -36.8 & -24.7 & 3.2 & 3.7 & 11.1 & 1.7 \\
\hline $1961-1990$ & -37.0 & -24.7 & 3.3 & 4.9 & 12.8 & 1.9 \\
\hline $1971-2000$ & -35.6 & -23.5 & 3.4 & 5.9 & 14.0 & 2.0 \\
\hline $1981-2010$ & -35.4 & -22.9 & 2.9 & 6.1 & 14.0 & 2.1 \\
\hline $1991-2020$ & -35.3 & -21.0 & 2.8 & 6.1 & 13.1 & 1.8 \\
\hline
\end{tabular}

The minimum air temperature that can be observed once per every 10 years varies from below $-35^{\circ} \mathrm{C}$ in the northeast up to $-23^{\circ} \mathrm{C}$ in southwest and $-21^{\circ} \mathrm{C}$ the Saaremaa Island (in 1991-2020) (Fig. 11a). When analysing changes in individual grid points, the largest $\mathrm{Tn}_{\mathrm{RL}} \mathrm{L}_{10}$ differences were found between 1951-1980 and 1991-2020. In some places, these differences are above $4^{\circ} \mathrm{C}$. The most prominent changes were observed in the central part of the analysed area and in the northwest (Fig. 11b).

The $\mathrm{RL}_{10}$ maximum January-February air temperature also increases moving from the northeast to southwest (from $6^{\circ} \mathrm{C}$ to $13^{\circ} \mathrm{C}$ ) (Fig. 12a). Comparing changes in individual grid points between $1951-$ 1980 and 1991-2020, it was found that the largest changes were in southeast (above $4^{\circ} \mathrm{C}$ ), while the smallest were in the north (below $2^{\circ} \mathrm{C}$ ) (Fig. 12b).

\section{Discussion And Conclusions}

In the eastern part of the Baltic Sea region, the average air temperature during the coldest winter month ranges from $-2.3^{\circ} \mathrm{C}$ in the southwest to $-8.7^{\circ} \mathrm{C}$ in the northeast. However, during extreme periods, the air temperature can drop below $-30^{\circ} \mathrm{C}$ or rise above $10^{\circ} \mathrm{C}$. These extremes always do a lot of damage to various areas of human activity or ecosystems and even can be a threat to human life. This study analyses such event dynamics in 1951-2020. Different indicators of cold and warm spells were calculated, such as absolute winter minimum/maximum temperatures, CSs and WSs reoccurrence and duration, and return level of extreme temperatures, which were also used in other studies as well (van Oldenborgh et al. 2019; Tomczyk et al. 2019; Spinoni et al. 2015; Matthes et al. 2015). 
Our study revealed quite strong changes in wintertime air temperature extremes. An absolute winter air temperature maximum has increased more than the minimum (the median trend values are $0.57^{\circ} \mathrm{C}$ and $0.44^{\circ} \mathrm{C}$ per decade, respectively). Tx trends for the whole study period are significant in the entire study area, while Tn only in a central part of the region.

Despite the increase in Tn temperatures over the last 70 year period, we did not find significant decreases in the occurrence of CSs. A record number of CSs were observed between 1961 and 1970 (median value is 15 cases per decade), however, during the last 5 decades (1971-2020) the number of CSs has remained stable. Usually 5-8 CSs per decade are observed. Our results complement the study of Sui et al. (2020), in which no significant decreasing trend was detected in the occurrence of extremely cold events in North Europe. Future model simulations in a study by Ayarzagüena and Screen (2016) also showed that the frequency of cold air outbreaks does not significantly change in high and middle latitudes of the $\mathrm{NH}$. However, the latter study found no significant changes in the future duration of cold air outbreaks from Arctic to mid-latitudes, while we found that the changes in the duration of CSs are much more significant. Over the last three decades, the number of CSs days had decreased by 1.5-2 times compared to the beginning of the investigation period. This shows that the average duration of a single CS is decreasing.

Much larger changes have been detected in the recurrence of WSs. A significant increase in the number of WSs was observed since the end of ninth decade of the 20th century. The number of years with at least one WS has also increased from 3-5 (1951-1990) to 5-8 (1991-2020) per decade. Our results also confirm, that WSs are not only becoming more frequent but also longer lasting. Over the last three decades, the duration of WSs has increased by 1.5-2 times compared to the period before 1988. Our findings fit well with the results of Tomczyk et al. (2019), where the statistically significant increase in wintertime number of warm days in Central Europe was determined. This study also indicates that the higher occurrence of WSs can be related to considerably more active and more intensive baric systems with an intensive advection of air masses from the south-west.

In our study, we determined statistically significant regime shifts in 1988 in TXx temperatures. The difference in mean values between two periods (1951-1987 and 1988-2020) as high as $2.7^{\circ} \mathrm{C}$, while during these two separate periods the TXx tendencies are negative. The fluctuations in TXx corresponds particularly well to changes in LSAC, such as AO $(r=0.72, p<0.05)$. A statistically significant regime shift was detected in the wintertime $A O$ index in 1989 as well. The fact that the regime shift in the DJF extreme temperature time series coincides with the shift in the winter $A O$ index time series allows us to claim that the very close relationship between these two parameters exist. Arctic oscillation is a dominant mode and one of the main driving forces of wintertime temperature extremes in many parts of the $\mathrm{NH}$. It has been shown that anomalously high/low AO index values tend to lead to anomalously warm/cold winters (Juzbaši et al. 2021; Cohen et al. 2010).

We also found statistically insignificant negative tendencies in the TNn time series in 1951-1987 and in 1988-2019 but the extremely warm year 2020 changed the sign of recent tendencies from negative to 
positive. Our results correspond well with the research of Johnson et al. (2018), which studied the recent levelling of temperature after the late 1990s and determined that during this global warming hiatus period (defined as 2002-2014) the occurrence of wintertime cold extremes increased over $\mathrm{NH}$ land. According to this study, the increase in cold extremes is associated with an atmospheric circulation pattern "warm Arctic-cold continents" (Johnson et al. 2018).

It is likely that global warming has a dual effect on extreme temperature events and some of the mechanisms involved in the formation of regional temperature anomalies act in the opposite directions. First, cold air outbreaks from the Arctic to middle latitudes became not as cold as they were in the past because of the Arctic amplification (Ayarzagüena and Screen 2016). On the other hand, the Arctic amplification to some extent may favour CSs in mid-latitudes, including Northern Europe (Cohen et al. 2020). Our results also suggest that CSs still are a common extreme event in the studied region. Moreover, the decreased occurrence of the positive phase of NAO in 1979-2015 (Vihma et al. 2020) and more frequent Scandinavian Pattern (Crasemann et al. 2017) during the last decades, undoubtedly resulted in statistically insignificant negative tendencies of extreme temperature after 1988 which were detected in our study as well. Another possible mechanism regarding how warm Arctic air is associated with an increase in severe winter weather across the continents of the $\mathrm{NH}$ involves a pathway through the stratosphere (Cohen et al. 2018). Several studies have been carried out to determine the typical features of the stratosphere-troposphere interactions during weather anomalies. Positive anomalies of the geopotential height at $250 \mathrm{hPa}$ level were determined 9 days (on average) before the beginning of WSs in Central Europe (Tomczyk et al. 2019). This indicates that the anomalies are descending from the upper troposphere to the lower. Previous studies (Hitchcock and Simpson 2014; Kretschmer et al. 2018) showed that anomalies in the stratospheric polar vortex tend to descend and can affect surface weather as well as changes in the $\mathrm{AO}$ phase.

The results of this study show that winter conditions in the analysed region are becoming more extreme as several WSs significantly increased, meanwhile the number of CSs only changed a little. These conditions are particularly unfavourable for ecosystems, agriculture, horticulture, and for winter sports. Even though the CSs are becoming milder, the effect of combined interactions with much more frequent WSs (often during the same winter season) is becoming even more threatening. Sulykovska and Wypych (2021) also highlighted that an increase in winter temperature extremes in Europe is accelerating. While most of the circulation structures associated with the occurrence of cold air outbreaks do not seem to change significantly in the future (Ayarzagüena and Screen 2016).

It is also important to note that not all changes were statistically significant in our study, but statistically significant results weren't obtained in other similar studies as well. The research of Tomczyk et al. (2019) also pointed out a lack of statistically significant changes in absolute temperature maximum in Central Europe. Statistically insignificant tendencies were obtained when analysing changes in the number of cold days in Northern Europe (Sui et al. 2020). In the study of Matthes et al. (2015), it was concluded that both types of spells show pronounced inter-annual and decadal variability, which complicates the analysis of their trends. This was confirmed in our study, especially in the case of Tn. 


\section{Declarations}

Competing Interests. The authors have no relevant financial or non-financial interests to disclose.

Acknowledgments. We acknowledge the E-OBS dataset from the EU-FP6 project UERRA (http://www.uerra.eu) and the Copernicus Climate Change Service, and the data providers in the ECA\&D project (https://www.ecad.eu).

Funding: This research was funded by European Social Fund under grant agreement with the Research Council of Lithuania (LMTLT) [grant number 09.3.3-LMT-K-712-02-0141].

Data Availability Statement: E-OBS temperature data are available online via the Copernicus Climate Data Store archive (https://cds.climate.copernicus.eu/cdsapp\#!/dataset/insitu-gridded-observations-europe? tab=overview (accessed on 10 September 2021)) and Arctic oscillation index data were downloaded from the NOAA Climate Prediction Centre website (accessed on 10 September 2021): https://www.cpc.ncep.noaa.gov/products/precip/CWlink/daily_ao_index/ao.shtml.

Author Contributions. Indrẻ Gečaitė: Conceptualization, Data curation, Methodology, Formal analysis, Visualization, Writing - original draft. Egidijus Rimkus: Supervision, Writing - review \& editing.

\section{References}

1. Alexander LV, Zhang X, Peterson TC, Caesar J, Gleason B, Klein Tank AMG, Haylock M, Collins D, Trewin B, Rahimzadeh F, Tagipour A, Rupa Kumar K, Revadekar J, Griffiths G, Vincent L, Stephenson DB, Burn J, Aguilar E, Brunet M, Taylor M, New M, Zhai P, Rusticucci M, Vazquez-Aguirre JL (2006) Global observed changes in daily climate extremes of temperature and precipitation. J Geophys Res 111: D05109. doi:10.1029/2005JD006290

2. Anagnostopoulou C, Tolika K, Lazoglou G, Maheras P (2017) The Exceptionally Cold January of 2017 over the Balkan Peninsula: A Climatological and Synoptic Analysis. Atmosphere 8: 252. https://doi.org/10.3390/atmos8120252

3. Ayarzagüena B, Screen JA (2016) Future Arctic sea ice loss reduces severity of cold air outbreaks in midlatitudes. Geophys Res Lett 43: 2801- 2809. doi:10.1002/2016GL068092

4. Beaugrand G, Conversi A, Chiba S, Edwards M, Fonda-Umani S, Greene C, Mantua N, Otto SA, Reid PC, Stachura MM, Stemmann L, Sugisaki H (2015) Synchronous marine pelagic regime shifts in the Northern Hemisphere. Philos Trans R Soc Lond B Biol Sci 370 1659:

20130272. https://doi.org/10.1098/rstb.2013.0272

5. Chapman SC, Murphy EJ, Stainforth DA, Watkins NW (2020) Trends in Winter Warm Spells in the Central England Temperature Record. J Appl Meteorol Climatol 59(6): 1069-

1076. https://doi.org/10.1175/JAMC-D-19-0267.1

6. Chemke R, Polvani LM (2020) Using multiple large ensembles to elucidate the discrepancy between the 1979-2019 modelled and observed Antarctic sea ice trends. Geophys Res Lett 47: 
e2020GL088339. https://doi.org/10.1029/2020GL088339

7. Christiansen B, Alvarez-Castro C, Christidis N, Ciavarella A, Colfescu I, Cowan T, Eden J, Hauser M, Hempelmann N, Klehmet K, Lott F, Nangini C, Jan van Oldenborgh G, Orth R, Stott P, Tett S, Vautard R, Wilcox L, Yiou P (2018) Was the cold European winter of 2009/10 modified by anthropogenic climate change? An attribution study. J Climate 31: 3387-410. https://doi.org/10.1175/JCLI-D-17-0589.1

8. Claud C, Duchiron B, Terray P (2007) Associations between large-scale atmospheric circulation and polar lows developments over the North Atlantic during winter. J Geophys Res 112: D12101. DOI:10.1029/2006JD008251

9. Cohen J, Foster J, Barlow M, Saito K, Jones J (2010) Winter 2009-2010: A case study of an extreme Arctic Oscillation event. Geophys Res Lett 37: L17707. doi:10.1029/2010GL044256

10. Cohen J, Pfeiffer K, Francis JA (2018) Warm Arctic episodes linked with increased frequency of extreme winter weather in the United States. Nat Commun 9(1):

869. https://doi.org/10.1038/s41467-018-02992-9

11. Cohen J, Zhang X, Francis J, Jung T, Kwok R, Overland J, Ballinger TJ, Bhatt US, Chen HW, Coumou D, Feldstein S, Gu H, Handorf D, Henderson G, Ionita M, Kretschmer M, Laliberte F, Lee S, Linderholm HW, Maslowski W, Peings Y, Pfeiffer K, Rigor I, Semmler T, Stroeve J, Taylor PC, Vavrus S, Vihma T, Wang S, Wendisch M, Wu Y, Yoon J (2020) Divergent consensuses on Arctic amplification influence on midlatitude severe winter weather. Nat Clim Chang 10: 20-29. https://doi.org/10.1038/s41558-0190662-y

12. Coles S, Bawa J, Trenner L, Dorazio P (2001) An Introduction to Statistical Modeling of Extreme Values. Springer, London, Volume 208

13. Conversi A, Fonda Umani S, Peluso T, Molinero JC, Santojanni A, Edwards M (2010) The Mediterranean Sea Regime Shift at the End of the 1980s, and Intriguing Parallelisms with Other European Basins. PloS one 5(5): e10633. https://doi.org/10.1371/journal.pone.0010633

14. Cornes R, van der Schrier G, van den Besselaar EJM, Jones PD (2018) An Ensemble Version of the EOBS Temperature and Precipitation Datasets. J Geophys Res Atmos 123. doi:10.1029/2017JD028200

15. Crasemann B, Handorf D, Jaiser R, Dethloff K, Nakamura T, Ukita J, Yamazaki K (2017) Can preferred atmospheric circulation patterns over the North-Atlantic-Eurasian region be associated with Arctic sea ice loss? Polar Sci 14: 9-20. doi:10.1016/j.polar.2017.09.002

16. Domonkos P, Piotrowicz K (1998) Winter temperature characteristics in Central Europe. Int J Climatol 18: 1405-1417.

17. Efthymiadis D, Goodess CM, Jones PD (2011) Trends in Mediterranean gridded temperature extremes and large-scale circulation influences. Nat. Hazards Earth Syst Sci 11: 2199-2214. https://doi.org/10.5194/nhess-11-2199-2011

18. Figura S, Livingstone DM, Hoehn E, Kipfer R (2011) Regime shift in groundwater temperature triggered by the Arctic Oscillation. Geophys Res Lett 38: L23401. doi:10.1029/2011GL049749 
19. Foster J, Cohen J, Robinson D, Estilow T (2013) A look at the date of snowmelt and correlations with the Arctic Oscillation. Ann Glaciol 54(62): 196-204. doi:10.3189/2013AoG62A090

20. Francis JA, Chan W, Leathers DJ, Miller JR, Veron DE (2009) Winter Northern Hemisphere weather patterns remember summer Arctic sea-ice extent. Geophys Res Lett 36: L07503. https://doi.org/10.1029/2009GL037274

21. Francis JA, Vavrus SJ (2012) Evidence linking Arctic amplification to extreme weather in midlatitudes. Geophys Res Lett 39: 801. https://doi.org/10.1029/2012GL051000

22. Gasparrini A, Guo Y, Hashizume M, Lavigne E, Zanobetti A, Schwartz J, Tobias A, Tong S, Rocklöv J, Forsberg B, Leone M, De Sario M, Bell ML, Guo YLL, Wu C, Kan H, Yi SM, de Sousa Zanotti Stagliorio Coelho M, Saldiva PHN Honda Y, Kim H, Armstrong B (2015) Mortality risk attributable to high and low ambient temperature: a multicountry observational study. Lancet 386(9991): 369-375. https://doi.org/10.1016/S0140-6736(14)62114-0

23. Gilleland E, Katz RW (2016) extRemes 2.0: an extreme value analysis package in R. J. Stat. Software. 1(8). https://doi.org/10.18637/jss.v072.i08

24. Graham RM, Cohen L, Petty AA, Boisvert LN, Rinke A, Hudson SR, Nicolaus M, Granskog MA (2017) Increasing frequency and duration of Arctic winter warming events. Geophys Res Lett 44: 69746983. doi:10.1002/2017GL073395

25. Guirguis K, Gershunov A, Schwartz R, Bennett S (2011) Recent warm and cold daily winter temperature extremes in the Northern Hemisphere. Geophys Res Lett 38:

L17701. doi:10.1029/2011GL048762

26. Hitchcock P, Simpson IR (2014) The downward influence of stratospheric sudden warmings. J Atmos Sci 71: 3856-3876. https://doi.org/10.1175/JAS-D-14-0012.1

27. Hosking JRM (1990) L-moments: Analysis and estimation of distributions using linear combinations of order statistics. J R Stat Soc Ser B 52: 105-124.

28. IPCC (2001) Climate Change 2001: The Scientific Basis. Contribution of Working Group I to the Third Assessment Report of the Intergovernmental Panel on Climate Change. Cambridge University Press, Cambridge, United Kingdom and New York. pp 881

29. Jiguet $F$, Brotons L, Devictor $V(2011)$ Community responses to extreme climatic conditions. Curr Zool 57: 406-413. https://doi.org/10.1093/czoolo/57.3.406

30. Johnson NC, Xie SP, Kosaka Y, Li X (2018) Increasing occurrence of cold and warm extremes during the recent global warming slowdown. Nat Commun 9:1724. https://doi.org/10.1038/s41467-01804040-y

31. Juzbaši A, Kryjov VN, Ahn JB (2021) On the anomalous development of the extremely intense positive Arctic Oscillation of the 2019-2020 winter. Environ Res Lett 16: 055008. https://doi.org/10.1088/1748-9326/abe434

32. Karl TR, Nicholls N, Ghazi A (1999) CLIVAR/GCOS/WMO workshop on indices and indicators for climate extremes. Clim Change 42: 3-7 
33. Kharin VV, Zwiers FW, Zhang X, Hegerl GC (2007) Changes in temperature and precipitation extremes in the IPCC ensemble of global coupled model simulations. J Clim 20(8): 1419-1444

34. Kodra E, Steinhaeuser K, Ganguly AR (2011) Persisting cold extremes under 21st-century warming scenarios. Geophys Res Lett 38: L08705. D0I:10.1029/2011GL047103

35. Kretschmer M, Coumou D, Agel L, Barlow M, Tziperman E, Cohen J (2018) More-Persistent Weak Stratospheric Polar Vortex States Linked to Cold Extremes. Bull Am Meteorol Soc 99(1): 49-60. https://doi.org/10.1175/BAMS-D-16-0259.1

36. Lavaysse Ch, Naumann G, Alfieri L, Salamon P, Vogt J (2019) Predictability of the European heat and cold waves. Clim Dyn 52: 2481-2495. https://doi.org/10.1007/s00382-018-4273-5

37. Lhotka O, Kyselý J (2015) Characterizing joint effects of spatial extent, temperature magnitude and duration of heat waves and cold spells over Central Europe. Int J Climatol 35(7): 1232-1244. https://doi.org/10.1002/joc.4050

38. Ma CS, Wang L, Zhang W, Rudolf VHW (2018) Resolving biological impacts of multiple heat waves: Interaction of hot and recovery days. Oikos 127: 622-633. https://doi.org/10.1111/oik.04699

39. Ma G, Rudolf VHW, Ma CS (2015) Extreme temperature events alter demographic rates, relative fitness, and community structure. Glob Change Biol 21:1794-1808. https://doi.org/10.1111/gcb.12654

40. Matthes H, Rinke A, Dethloff K (2015) Recent changes in Arctic temperature extremes: warm and cold spells during winter and summer. Environ Res Lett 10: 11402. doi:10.1088/1748-9326/11/2/029501

41. McMichael AJ, Powles JW, Butler CD, Uauy R (2007) Food, livestock production, energy, climate change, and health. Lancet 370(9594): 1253-1263. https://doi.org/10.1016/S0140-6736(07)61256-2

42. Mori M, Watanabe M, Shiogama H, Inoue J, Kimoto M (2014) Robust Arctic sea-ice influence on the frequent Eurasian cold winters in past decades. Nature Geosci 7: 869-873. https://doi.org/10.1038/ngeo2277

43. Nakamura T, Yamazaki K, Iwamoto K, Honda M, Miyoshi Y, Ogawa Y, Ukita J (2015) A negative phase shift of the winter AO/NAO due to the recent Arctic sea-ice reduction in late autumn. J Geophys Res Atmos 120: 3209-3227. https://doi.org/10.1002/2014JD022848

44. Nikolova N, Penev D (2007) Fluctuation of Extremely Cold and Warm Months in Bulgaria. Geogr Pannonica 11: 19-21

45. Outten SD, Esau I (2012) A link between Arctic sea ice and recent cooling trends over Eurasia. Clim Change 110: 1069-1075. https://doi.org/10.1007/s10584-011-0334-z

46. Overland JE, Wood KR, Wang M (2011) Warm Arctic-cold continents: climate impacts of the newly open Arctic Sea. Polar Res 30:1. https://doi.org/10.3402/polar.v30i0.15787

47. Paciorek CJ, Stone DA, Wehner MF (2018) Quantifying statistical uncertainty in the attribution of human influence on severe weather. Weather Clim Extrem 20: 6980. https://doi.org/10.1016/j.wace.2018.01.002 
48. Rodionov SN (2004) A sequential algorithm for testing climate regime shifts. Geophys Res Lett 31: L09204. doi:10.1029/2004GL019448

49. Ruosteenoja K, Markkanen T, Räisänen J (2020) Thermal seasons in northern Europe in projected future climate. Int J Climatol 40: 4444- 4462. https://doi.org/10.1002/joc.6466

50. Rusticucci M, Tencer B (2008) Observed Changes in Return Values of Annual Temperature Extremes over Argentina. J Clim 21(21): 5455-5467. https://doi.org/10.1175/2008JCLI2190.1

51. Rutgersson A, Jaagus J, Schenk F, Stendel M, Bärring L, and co-authors (2015) The BACC II Author Team (Ed.). Recent change-atmosphere. In: Second Assessment of Climate Change for the Baltic Sea Basin. Regional Climate Studies. Springer, Cham. pp 69-97

52. Sillmann J, Croci-Maspoli M (2009) Present and future atmospheric blocking and its impact on European mean and extreme climate. Geophys Res Lett 36: L10702. https://doi.org/10.1029/2009GL038259

53. Sillmann J, Croci-Maspoli M, Kallache M, Katz RW (2011) Extreme cold winter temperatures in Europe under the influence of North Atlantic atmospheric blocking. J Clim 24: 5899-5913. https://doi.org/10.1175/2011JCLI4075.1

54. Sillmann J, Kharin VV, Zhang X, Zwiers FW, Bronaugh D (2013). Climate extremes indices in the CMIP5 multimodel ensemble: Part1. Model evaluation in the present climate. J Geophys Res 118(4): 1716-1733. https://doi.org/10.1002/jgrd.50203

55. Smid M, Russo S, Costa AC, Granell C, Pebesma E (2019) Ranking European capitals by exposure to heat waves and cold waves. Urban Clim 27: 388-402. https://doi.org/10.1016/j.uclim.2018.12.010

56. Spinoni J, Lakatos M, Szentimrey T, Bihari Z, Szalai S, Vogt J, Antofie T (2015) Heat and cold waves trends in the Carpathian Region from 1961 to 2010. Int J Climatol 35: 41974209. https://doi.org/10.1002/joc.4279

57. Sui Ch, Yu L, Vihma T (2020) Occurrence and drivers of wintertime temperature extremes in Northern Europe during 1979-2016. Tellus A Dyn Meteorol Oceanogr 72(1): 1-19. https://doi.org/10.1080/16000870.2020.1788368

58. Sulikowska A, Wypych A (2021) Seasonal Variability of Trends in Regional Hot and Warm Temperature Extremes in Europe. Atmosphere 12(5): 612. https://doi.org/10.3390/atmos12050612

59. Tang Q, Zhang X, Yang X, Francis JA (2013) Cold winter extremes in northern continents linked to Arctic sea ice loss. Environ Res Lett 8(1): 4-36. DOI:10.1088/1748-9326/8/1/014036

60. Tomassini L, Gerber EP, Baldwin MP, Bunzel F, Giorgetta M (2012) The role of stratospheretroposphere coupling in the occurrence of extreme winter cold spells over northern Europe. J adv model earth syst 4: M00A03. DOI:10.1029/2012MS000177

61. Tomczyk AM, Sulikowska A, Bednorz E, Półrolniczak M (2019) Atmospheric circulation conditions during winter warm spells in Central Europe. Nat Hazards 96: 1413-1428. https://doi.org/10.1007/s11069-019-03621-4

62. Vallis GK, Zurita-Gotor P, Cairns C, Kidston J (2015) Response of the large-scale structure of the atmosphere to global warming. Q J R Meteorol Soc 141: 1479-1501. 
https://doi.org/10.1002/qj.2456

63. van Oldenborgh GJ, Haarsma R, De Vries H, Allen MR (2015) Cold extremes in north america versus mild weather in Europe: the winter of 2013-14 in the context of a warming world. Bull Am Meteorol Soc 96: 707-714. https://doi.org/10.1175/BAMS-D-14-00036.1

64. van Oldenborgh GJ, Mitchell-Larson E, Vecchi GA, De Vries H, Vautard R, Ottoet F (2019) Cold waves are getting milder in the northern midlatitudes. Environ Res Lett 14: 11400. DOI:10.1088/17489326/ab4867

65. Vavrus SJ (2018) The Influence of Arctic Amplification on Mid-latitude Weather and Climate. Curr Clim Change Rep 4: 238-249. https://doi.org/10.1007/s40641-018-0105-2

66. Vihma T (2014) Effects of Arctic Sea Ice Decline on Weather and Climate: A Review Surv Geophys 35(5): 1175-1214. https://doi.org/10.1007/s10712-014-9284-0

67. Vihma T (2017) Weather Extremes Linked to Interaction of the Arctic and Midlatitudes. Climate Extremes, pp 39-50. https://doi.org/10.1002/9781119068020.ch2.

68. Vihma T, Graversen R, Chen L, Handorf D, Skific N, Francis JA, Tyrrell N, Hall R, Hanna E, Uotila P, Dethloff K, Karpechko AY, Björnsson H, Overland JE (2020) Effects of the tropospheric large-scale circulation on European winter temperatures during the period of amplified Arctic warming. Int $J$ Climatol 40: 509- 529. https://doi.org/10.1002/joc.6225

\section{Figures}

\section{Figure 1}

The study area and long term (1951-2020) average air temperatures $\left({ }^{\circ} \mathrm{C}\right)$ in January (left) and July (right)

\section{Figure 2}

Fluctuations and trends of the regionally averaged annual (a) December-February (DJF) absolute minimum (TNn) and (b) January-February (JF) absolute maximum (TXX) temperatures $\left({ }^{\circ} \mathrm{C}\right)$ in the eastern part of the Baltic Sea region, and (c) DJF Arctic oscillation (AO) index in 1951-2020

\section{Figure 3}


Trend values ( ${ }^{\circ} \mathrm{C} /$ decade) of wintertime absolute minimum temperature (Tn) in: a) 1951-2020, b) 19511987, and c) 1988-2020; the asterisks show statistically significant $(p<0.05)$ changes

\section{Figure 4}

Trend values ( ${ }^{\circ} \mathrm{C} /$ decade) of January-February absolute maximum temperature (Tx): a) 1951-2020, b) 1951-1987, and c) 1988-2020; the asterisks show statistically significant $(p<0.05)$ changes

(a)

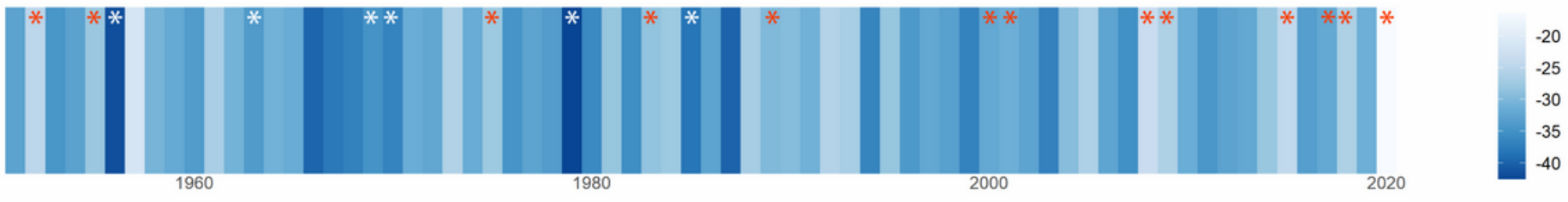

(b)

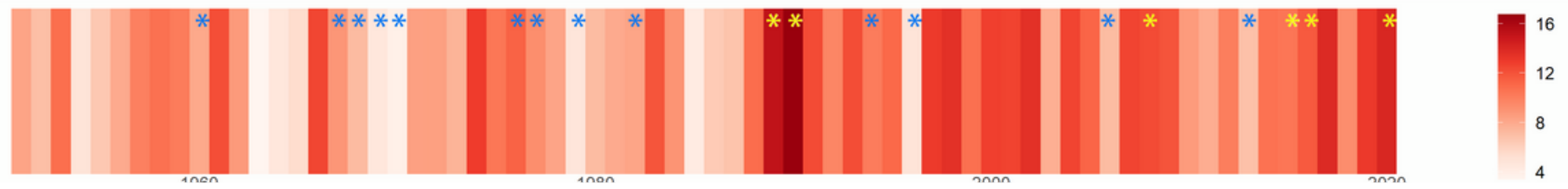

\section{Figure 5}

Mean regional absolute a) minimum ( $T N n)$ and $b$ ) maximum (TXx) temperature. Years with four or more CSs/WSs marked with a white/yellow asterisk, while years without CSs/WSs were marked with a red/blue asterisk

\section{Figure 6}

The total number of winter CSs per decade in the eastern Baltic Sea region

\section{Figure 7}

The total number of winter WSs per decade in the eastern part of Baltic Sea region 


\section{Figure 8}

Total number (dashed line) and difference (CSs-WSs; red and blue bars) of the regionally averaged (over 97 grid points) number of CSs and WSs in the eastern Baltic Sea region in 1951-2020

\section{Figure 9}

The total duration (days) of CSs per decade in the eastern part of Baltic Sea region

\section{Figure 10}

The total duration (days) of WSs per decade in the eastern part of Baltic Sea region

\section{Figure 11}

The $\mathrm{RL}_{10}\left({ }^{\circ} \mathrm{C}\right)$ of $\mathrm{Tn}$ in the eastern part of the Baltic Sea region in a) 1991-2020 and b) the difference between $\mathrm{RL}_{10}$ values in two periods: 1991-2020 minus 1951-1980

\section{Figure 12}

The $\mathrm{RL}_{10}\left({ }^{\circ} \mathrm{C}\right)$ of $\mathrm{Tx}$ in the eastern part of the Baltic Sea region in a) 1991-2020 and b) the difference between $\mathrm{RL}_{10}$ values in two periods: 1991-2020 minus 1951-1980 